\title{
STUDI KELIMPAHAN DAN KEANEKARAGAMAN MAKROZOOBENTOS DI PERAIRAN BEDAGAI, KECAMATAN TANJUNG BERINGIN KABUPATEN SERDANG BEDAGAI
}

\author{
Hendro Pranoto \\ Jurusan Biologi, Universitas Negeri Medan \\ hendro_p.unimed@yahoo.co.id
}

\begin{abstract}
ABSTRAK
Penelitian ini bertujuan untuk mengetahui kelimpahan, keanekaraaman, keseragaman, dan dominansi Makrozoobentos yang terdapat di Perairan Bedagai serta faktor fisika -kimia perairan. Pengambilan sampel dilakukan pada 4 (empat) stasiun berdasarkan rona lingkungannya. Populasi penelitian adalah seluruh makrozoobentos yang terdapat di Perairan Bedagai, sedangkan sampelnya adalah makrozoobentos yang berhasil tertangkap dengan Eckmangrab.

Metode penelitian adalah deskriptif survei. Hasil penelitian menunjukkan, bahwa di Perairan Bedagai ditemukan 18 taksa makrozoobentos yang terdiri dari 13 Gastrpoda, 3 Annelida, dan 2 Arthropoda. Kelimpahan total makrozoobentos yang ditemukan selama penelitian berkisar antara 1506,56 - 2692,31 ind $/ \mathrm{m}^{2}$, makrozoobentos yang dominan ditemukan adalah Pagurus sp $(801,28)$ ind $/ \mathrm{m}^{2}$ )

Indeks keanekaragaman, indeks keseragaman dan ideks dominansi makrozoobentos di perairan bedagai selama penelitian masing-masing berkisar antara 1,96 - 2,42: 0,707 - 0,894: 0,11 0,9513 .

Faktor kimia-fisika perairan seperti suhu, kecerahan, kekeruhan, intensitas cahaya, oksigen terlarut (DO), $\mathrm{pH}, \mathrm{BOD}_{5}$ dan salinitas masih mendukung kehidupan biota perairan.
\end{abstract}

Kata kunci : Makrozoobentos, fisiki-kimia perairan, Serdang Bedagai

\section{STUDY OF ABUNDANCE AND DIVERSITY OF MACROZOOBENTOS IN BEDAGAI WATERS, KECAMATAN TANJUNG BERINGIN , KABUPATEN SERDANG BEDAGAI}

This study aims to determine the abundance, diversity, uniformity, and dominance of Macrozoobentos found in Bedagai waters as well as physico-chemical factors. Sampling is done on 4 (four) stations based on the environmental tone. The study population was all macrozoobentos found in Bedagai waters, while the samples were macrozoobentos which were caught with Eckmangrab.

The research method is descriptive survey. The results showed that in Bedagai waters found 18 taxa macrozoobentos consisting of 13 Gastrpoda, 3 Annelida, and 2 Arthropoda. The total abundance of macrozoobenthos found during the study ranged from 1506.56 - 2692.31 ind / $\mathrm{m} 2$, the dominant macrozoobentos found was Pagurus sp (801.28) ind / m2)

The index of diversity, uniformity index and ideks of dominance of makrozoobentos in Bedagai waters during their respective studies ranged from 1.96 - 2.42: $0.707-0.894: 0.11$ - 0.9513.Chemical-physical factors such as temperature, brightness, turbidity, light intensity, dissolved oxygen (D0), pH, BOD5 and salinity still support the life of aquatic biota

\section{Key Words : Macrozoobentos, physico-chemical factors, Serdang Bedagai}

\section{Pendahuluan}

Perairan Bedagai terletak di kecamatan Tanjung Beringin Kabupaten Serdang Bedagai. Perairan Bedagai mengalir dri hulu sungai yang berasal dari kecamatan Sei Rampah. Jaraknya lebih kurang $5 \mathrm{~km}$ dari kota Sei Rampah kearah timur dan bermuara ke Perairan Bedagai yang berhubungan langsung dengan Pantai Sialang Buah.

Air tawar, air payau dan airlaut merupakan tiga ekosistem perairan yang pemanfatnnya dapat menimbulkan dampak negatif. Hal ini tentu saja dapat mempengaruhi baik kualitas faktor fisik, kimia maupun biologi perairan tersebut.

Berdasarkan pantauan penulis bahwa aliran sungai di perairan Bedagai yang dulunya masih layak konsumsi sekarang tidak lagi. Hal ini disebabkan oleh pengaruh berdirinya pabrik tapioka di kota Sei Rampah yang limbahnya langsung di buang ke sungai tanpa mengalami penyaringan terlebih dahulu, akibatnya air berubah warna menjadi hitam dan berbau, dan pembuangan sampah domestik penduduk 
setempat menyebabkan perairan Bedagai tidak memenuhi standar kesehatan untuk dikonsumsi oleh penduduk. Namun demikian menurut pantauan penulis, saat ini penduduk sekitar perairan Bedagai masih memanfaatkannya untuk MCK (mandi, cuci, kakus).

Dengan tercemarnya perairan Bedagai akibat dari limbah dan sampah domestik maka keadaan seperti ini dapat mempengaruhi kelangsungan hidup berbagai jenis hidrobiota yang hidup didalamnya termasuk organisme makrozoobentos.

Keragaman makrozoobentos dapat menggambarkan kualitas perairan. Jika hanya hewan makrozoobentos tertentu yang ditemukan, dapat diperkirakan bahwa perairan tersebut telah tercemar, contohnya tubifex SP. Keragaman hewan makrozoobentos tidak cukup untuk menentukan kualitas suatu perairan,tetapi harus didukung oleh faktor fisika kimia yang juga memberi pengaruh terhadap suatu perairan (Sinambela,1994).

Bertitik tolak dari latar belakang tersebut penulis merasa tertarik untuk mengadakan penelitian tentang keanekaragaman, kelimpahan, keragaman, dan dominansi dari makrozoobentos di perairan Bedagai Kecamatan Tanjung Beringin Kabupaten Serdang Bedagai.

\section{Bahan dan Metode}

Populasi penelitian adalah seluruh makrozoobentos yang terdapat diperairan Bedagai. Sedangkan sampelnya adalah makrozobentos yang tertangkap didalam Eckmangrab.

Metode yang digunakan adalah metode deskriptif survei. Sedangkan pengambilan sampel ditetapkan pada empat stasiun dengan tiga kali pengambilan sampel. Penentuan stasiun penelitian dibuat berdasarkan rona lingkungan dimana stasiun I terletak di hulu sungai, staiun II berada di pemukiman penduduk, stasiun III di daerah hutan mangrove dan stasiun IV berada di daerah estuaria.

Sampel makrozoobentos diambil dengan menggunakan Eckmangrab yang berukuran panjang $16 \mathrm{~cm}$ dan lebar $13 \mathrm{~cm}$. Substrat yang diambil disaring dengan menggunakan saringan bertingkat dengan ukuran mata saringan 35 $850 \mathrm{~mm}$. Makrozoobentos yang tersaring dibersihkan dan diawetkan dalam larutan formalin $10 \%$ kemudian di identifikasi. Nilai kelimpahan, indeks keanekaragaman dihitung dengan menggunakan Shannon - Wienner dalam Krebs (1978) serta indeks keseragaman dihitung dengan menggunakan rumus (Brown dan Zar, 1977 dalam Sinaga dan Rewayati, 1999) serta indeks dominansi (Odum, 1993 dalam Sinaga dan Rewayati, 1999).

\section{Hasil Dan Pembahasan}

A. Faktor fisika - kimia Perairan Bedagai Hasil pengamatan dan pengukuran beberapa faktor fisika-kimia di perairan Bedagai disajikan dalam tabel 1 berikut:

Tabel 1. Data pengukuran faktor fisika-kimia di perairan Bedagai Kabupaten Serdang Bedagai.

\begin{tabular}{|c|c|c|c|c|}
\hline \multirow[t]{2}{*}{ Parameter } & \multicolumn{4}{|c|}{ Stasiun } \\
\hline & $\mathrm{I}$ & II & III & IV \\
\hline I. Fisika & & & & \\
\hline - Suhu $\left({ }^{\circ} \mathrm{C}\right)$ & 29,50 & 29,35 & 28,50 & 29,75 \\
\hline - Kecerahan $(\mathrm{cm})$ & 60,00 & 51,00 & 70,00 & 69,00 \\
\hline - Kekeruhan (NTU) & 35,50 & 45,55 & 30,95 & 28,00 \\
\hline - Intensitas Cahaya & 4300 & 4465 & 4520 & 4555 \\
\hline II. Kimia & & & & \\
\hline - DO (mg/l) & 3,50 & 2,10 & 3,75 & 3,60 \\
\hline - $\mathrm{pH}$ & 6,72 & 6,51 & 6,76 & 6,00 \\
\hline - $\mathrm{BOD}_{5}(\mathrm{mg} / \mathrm{l})$ & 8,50 & 11,25 & 8,55 & 8,50 \\
\hline - Salinitas & 30,00 & 31,00 & 32,00 & 33,0 \\
\hline - Nitrat (mg/l) & 0,70 & 1,22 & 1,15 & 0,90 \\
\hline
\end{tabular}

1.

Suhu

Berdasarkan hasil pengukuran dari keempat stasiun, suhu berkisar antara 28,50 - 29, $75{ }^{\circ} \mathrm{C}$. Suhu tertinggi $29,75{ }^{\circ} \mathrm{C}$ terdapat pada stasiun IV yang berada di lokasi estuaria, sedangkan suhu terendah $28,50{ }^{\circ} \mathrm{C}$ terdapat pada stasiun III, berada pada lokasi hutan mangrove. Rendahnya suhu pada stasiun ini diduga karena mendapat naungan pepohonan dan masih sedikit menerima limbah organik. Meningkatnya suhu air pada stasiun I, II dan IV serta suhu tertinggi pada stasiun IV diduga lebih besar dipengaruhi oleh keterbukan perairan tersebut. Disamping itu juga karena perbedaan waktu dan keadaan cuaca pada saat pengukuran dilakukan. Sinaga dan Riwayati (1998) mengatakan, dengan semakin 
terbukanya suatu perairan dari naungan akan semakin cepat proses transfer panas cahaya matahari dibandingkan dengan daerah yang mendapat naungan.

Perbedaan suhu antar stasiun pengamatan masih berada dikisaran normal bagi organisme akuatik. Lebih jelasnya Alabastar (1980) mengatakan, kisaran suhu optimum bagi kehidupan organisme akuatik adalah $18{ }^{\circ} \mathrm{C}-30$ ${ }^{\circ} \mathrm{C}$. Kisaran suhu di Perairan Bedagai menunjukkan bahwa suhu air masih mendukung terhadap kehidupan organisme.

2. Kecerahan

Berdasarkan hasil pengukuran dari keempat stasiun pengamatan , kecerahan berkisar antara 51,00 - 70,00 cm terdapat pada stasiun III yang berada di lokasi hutan mangrove, sedangkan kecerahan terendah 51,00 terdapat pada stasiun II yang berada dilokasi pemukiman penduduk. Kecerahan perairan secara tidak langsung menggambarkan kekeruhan dan muatan padatan tersuspensi yang dipengaruhi oleh banyaknya partikel yang ada di dalam perairan.

Kecerahan dapat berkisar beberapa senti meter pada air yang sangat keruh dan sampai 40 $\mathrm{cm}$ pada air yang sangat jernih (Sinaga dan Riwayati 1998). Berkaitan dengan hal tersebut, maka dari keempat stasiun pengamatan, tingkat kecerahannya tergolong tinggi. Hal ini diduga karena perairan ini masih sedikit menerima limbah organik.

\section{Kekeruhan}

Berdasarkan hasil pengukuran dari keempat stasiun pengamatan, kekeruhan berkisar antara 28,80 - 45,55 NTU. Kekeruhan tertinggi 45,55 NTU terdapat pada stasiun II yang beraada di lokasi pemukiman penduduk dan terjadi aktivitas penduduk sehari hari (MCK) di sekitar Perairan Bedagai tersebut. Sedangkan kekeruhan terendah 28,80 NTU terdapat pada stasiun IV yang berada di lokasi estuaria.

Sinaga dan Riwayati (1998) menyatakan, pada mulut estuaria biasanya kekeruhan minimum, karena penuhnya air laut dan semakin keruh bila mengalir kearah pedalaman.

4. Intensitas Cahaya

Berdasarkan hasil pengukuran dari keempat stasiun pengamatan di Perairan Bedagai, intensitas cahaya berkisar antara 4300 - 4555 lux, intensitas cahaya tertingi 4555 lux terdapat pada stasiun IV yang berada di lokasi estuaria. Sedangkan intensitas cahaya terendah 4300 lux terdapat pada stasiun I yang berada di lokasi hulu sungai.

Tinggi rendahnya intensitas cahaya yang sampai pada permukaan perairan tergantung pada waktu dilakukan pengukuran dan keadaan iklim/cuaca yang terjadi pada saat pengukuran dilakukan. Di dalam suatu perairan, fotosintesis meningkat sejalan dengan meningkatnya intensitas cahaya.

5. Kandungan Oksigen Terlarut (DO)

Berdasarkan hasil pengukuran dari keempat stasiun pengamatan, DO berkisar antara $2,10-3,75 \mathrm{mg} / \mathrm{l}$. DO tertinggi 3,75 mg/l terdapat pada stasiun III yang berada di dilokasi hutan mangrove. Sedangkan DO yang terendah 2,10 $\mathrm{mg} / \mathrm{l}$ terdapat pada stasiun II yang berada dilokasi pemukiman penduduk. Rendahnya oksigen terlarut terendah terdapat pada stasiun II yang diduga karena banyaknya akumulasi bahan organik yang diterima perairan tersebut, sehingga oksigen banyak dibutuhkan oleh bakteri aerobik untuk menguraikan bahan-bahan organik tersebut.

Tingginya nilai DO pada stasiun III, hal ini disebabkan perairan agak dangkal, adanya pengadukan oleh hempasan ombak-ombak kecil. Lebih jelasnya Sinaga dan Riwayati (1998) mengatakan, dangkalnya air, luasnya permukaan air dan air yang selalu bergerak, kesemuanya itu mengakibatkan kandungan oksigen perairan relatif tinggi. Menurut Sastrawijaya (1991), bila suhu perairan rendah maka kadar oksigennya akan tinggi begitu juga sebaliknya. Kandungan oksigen terlarut dapat dihubungkan dengan kualitas suatu perairan. Berdasarkan penggolongan kualitas air (Lee, et. al.,1978), bahwa Perairan Bedagai tercemar sedang. Sedangkan untuk keperluan organisme akuatik dapt dikatakan masih layak bagi kehidupan makrozoobentos yang terdapat didalamnya.

6. Derajat Keasaman (pH)

Berdasarkan hasil pengukuran dari keempat stasiun pengamatan, $\mathrm{pH}$ berkisar antara 6,51 - 6,80. pH tertinggi 6,51 terdapat pada stasiun IV yang berada di lokasi estuaria. Sedangkan $\mathrm{pH}$ yang terendah 6,80 terdapat pada stasiun II yang berada di lokasi pemukiman penduduk.

Adanya perbedaan pH ini diduga karena adanya masukan limbah organik dari penduduk setempat. Masuknya limbah organik tersebut akan mengakibatkan meningkatnya $\mathrm{CO}_{2}$ dan hal ini dapat menurunkan nilai $\mathrm{pH}$ pada stasiun II. Selanjutnya Pescod (1973) mengatakan, perairan yang mempunyai pH sekitar 6,5 - 8,5 merupakan perairan yang baik bagi biota perairan, termasuk makrozoobentos. Bertitik tolak dari sini maka Perairan Bedagai merupakan perairan yang aman bagi biota perairan.

7. Kebutuhan Oksigen Biologis atau Biological Oxygen $\left(\mathrm{BOD}_{5}\right)$

Berdasarkan hasil pengukuran dari keempat stasiun pengamatan, $\mathrm{BOD}_{5}$ berkisar 
antara 8,50 - 11,25 mg/l. BOD $_{5}$ tertinggi 11,25 $\mathrm{mg} / \mathrm{l}$ terdapat pada stasiun II yang berada di di lokasi pemukiman penduduk. Sedangkan BOD $_{5}$ yang terendah $8,50 \mathrm{mg} / \mathrm{l}$ terdapat pada stasiun I yang berada di lokasi hulu sungai.

Nilai BOD5 antara sataiun I, III dan IV hampir sama, yaitu 5,0 mg/l, 8,55 mg/l dan 8,9 $\mathrm{mg} / \mathrm{l}$ dan sangat jauh berbeda dengan stasiun II, yaitu 11,25 mg/l. Rendahnya nilai BOD5 pada stasiun I, III dan IV, hal ini disebabkan karena lokasi ketiga stasiun tersebut jauh dari pemukiman penduduk dan lepas dari gangguan masyarakat. Sedangkan pada stasiun II berada pada pemukiman penduduk, sehingga daerah ini banyak mendapat sampah (limbah) dari masyarakat setempat. Hal ini akan menyebabkan berlimpahnya bakteri untuk menguraikan bahanbahan organik tersebut.

Fluktuasi nilai BOD sangat ditentukan oleh komposisi sampah yang masuk kedalam perairan. Semakin banyak bahan-bahan yang mudah terurai, semakin tinggi nilai BOD nya. Hawkes (1978) mengatakan, dalam suatu perairan yang mengandung banyak pemasukan oksigen, sehingga akan terjadi pengurangan kadar oksigen dalam perairan atau bahkan oksigen akan habis. Selanjutnya Lee, et. al. (1978) mengatakan, tingkat pencemaran suatu perairan dapat ditentukan berdasarkan nilai BOD5. Bertitik tolak dari penggolongan tersebut kualitas Perairan Bedagai dapat dikategorikan kedalam keadaan tercemar sedang.

\section{Salinitas}

Berdasarkan hasil pengukuran dari keempat stasiun pengamatan, salinitas berkisar antara 30,00 - 33,00. Salinitas tertinggi 33,00 terdapat pada stasiun IV yang berada di di lokasi estuaria. Sedangkan salinitas yang terendah 30,00 terdapat pada stasiun I yang berada di lokasi hulu sungai. Nilai salinitas dari stasiun I sampai dengan IV berturut turut, yakni 30,00; 31,$00 ; 32,00 ; 33,00$. Nilai salinitas ini cendrung meningkat dari stasiun I sampai dengan IV . adanya variasi salinitas pada setiap stasiun tergantung pada musim, topograf estuaria, pasang surut dan jumlah air tawar yang masuk. Pasang surut dapat mengakibatkan terjadinya perubahan salinitas. Pada pasang naik air laut masuk jauh ke arah hulu, sebaliknya pada pasang surut air tawar masuk kearah hilir.

Ditinjau dari variasi ini, Perairan Bedagai masih tergolong dalam kisaran yang baik guna mendukung biota perairan, khusunya makrozoobentos.

9. Nitrat $\left(\mathrm{NO}_{3}\right)$

Dari hasil pengamatan yang diperoleh selama penelitian, kandungan nitrat berkisar 0,70-1,22 $\mathrm{mg} / \mathrm{l}$. Kandungan nitrat tertinggi terdapat pada stasiun II dan terendah di stasiun IV. Tingginya kandungan nitrat diduga karena adanya pembuangan limbah industri dan juga adanya kotoran hewan dan manusia.

\section{B. Keanekaragaman, Kelimpahan, Keseragaman dan Dominansi Makrozoobentos.}

Tabel 2. Data Kelimpahan, Indeks Keanekaragaman, Keseragaman dan Dominansi Makrozoobentos Di Perairan Bedagai Kabupaten Serdang Bedagai.

\begin{tabular}{|c|c|c|c|c|}
\hline \multirow[t]{2}{*}{ Spesies } & \multicolumn{4}{|c|}{$\begin{array}{c}\text { STASIUN } \\
\text { (Individu } / \mathrm{m}^{2} \text { ) }\end{array}$} \\
\hline & $\mathrm{I}$ & II & III & IV \\
\hline \multicolumn{5}{|l|}{ ANNELIDA } \\
\hline 1. $\quad$ Nereis & 304,49 & 320,15 & 304,49 & 176,28 \\
\hline 2. Owenia $s p$ & 256,41 & & 336,54 & 208,33 \\
\hline 3. Sabella $s p$ & 192,31 & 208,33 & - & - \\
\hline \multicolumn{5}{|l|}{ GASTROPODA } \\
\hline 1. Murex & - & 32,05 & 48,08 & 80,13 \\
\hline 2. Turritella terebra & - & 16,03 & 32,05 & 64,10 \\
\hline 3. Telescopium & - & 32,05 & 48,08 & 64,10 \\
\hline 4. Cerihidea angulata & 96,15 & 80,13 & 128,21 & 144,23 \\
\hline 5. Nassarius stdatus & - & 16,03 & 48,08 & 80,13 \\
\hline 6. Conus sp & - & - & 16,03 & 16,03 \\
\hline 7. Thais carinifera & - & 16,03 & 32,05 & 48,08 \\
\hline 8. Natica trigna & - & 16,03 & 16,03 & 32,05 \\
\hline 9. Syrinx arnanus & - & - & 16,03 & 32,05 \\
\hline 10. Mya arenaria & 160,26 & 144,23 & 176,28 & 240,38 \\
\hline 11. Anadara sp & 16,03 & 16,03 & 48,08 & - \\
\hline 12. Petricola phdandi formis & 80,13 & 96,15 & 96,15 & 112,18 \\
\hline
\end{tabular}




\begin{tabular}{lllll}
\hline 13. Tagallus pluballus & 16,03 & 16,03 & 48,08 & 64,10 \\
\hline ARTROPODA & & & & \\
\hline 1. Paratomella cyrpris & 128,21 & - & - & 528,85 \\
\hline 2. Pagurus $s p$ & 336,54 & 384,62 & 512,82 & 801,28 \\
\hline Jumlah Taksa & 10 & 15 & 16 & 16 \\
\hline Kelimpahan Total $\left(\mathrm{Ind} / \mathrm{m}^{2}\right)$ & 1586,56 & 1618,61 & 1907,08 & 2692,31 \\
\hline Indeks Keanekaragaman $(\mathrm{H})$ & 2,04 & 2,42 & 1,96 & 2,22 \\
\hline Indeks Keseragaman (E) & 0,885 & 0,894 & 0,707 & 0,801 \\
\hline Indeks Dominansi (C) & 0,11 & 0,1475 & 0,1479 & 0,9513 \\
\hline
\end{tabular}

1. Kelimpahan Makrozoobentos

Kelimpahan makrozoobentos berkisar antara 1586,56 - 2692,31 ind $/ \mathrm{m}^{2}$. Kelimpahan tertinggi terdapat pada stasiun IV yaitu 2692,31 ind $/ \mathrm{m}^{2}$ dan terendah pada stasiun I yaitu 1586,56 ind $/ \mathrm{m}^{2}$. Rendahnya kelimpahan makrozoobentos pada stasiun I dibandingkan dengan stasiun IV ini berhubungan dengan faktor kimia fisika perairan. Semakin buruk kualitas perairan cenderung mengurangi jumlah organisme makrozoobentos yang hidup di daerah tersebut. Namun organisme yang mempunyai toleransi yang tinggi terhadap kondisi lingkungan yang buruk cendrung kelimpahan individunya bertambah (Ravera, 1979 dalam Fachrul, 2007).

Dari hasil penelitian diperoleh 18 taksa yang terdiri dari 13 taksa gastropoda 3 taksa annelida dan 2 taksa antropoda.

2. Indeks Keanekaragaman Makrozoobentos Keanekaragaman makrozoobentos berkisar antara $10-16$ taksa, indeks keanekaragaman berkisar antara 1,96 - 2,42. Nilai indeks keanekaragaman yang demikian tergolong rendah (Krebs, 1972). Kenekaragaman tertinggi terdapat pada stasiun II yaitu 2,42. Sedangkan keanekaragaman terendah terdapat pada stasiun III. Hal ini diduga karena faktor fisika kimia yang membatasi daya toleransi terhadap spesies tertentu.

Jika dibandingkan antara stasiun IV dengan stasiun II, indeks keanekaragaman masing-masing stasiun hampir sama yakni 2,22 2,42 . Berarti benar apa yang dikatakan Odum (1971), bahwa keaneragaman spesies juga dipengaruhi oleh penyebaran atau pembagian individu dalam tiap spesies, karena suatu komunitas walaupun mempunyai banyak spesies tapi bila pembagian individunya tidak merata dalam tiap spesies, maka keanekaragaman spesies dinilai rendah.

Disamping itu lingkungan biotik dan abiotik akan mempengaruhi kelimpahan maupun keanekaragaman suatu organisme, hal ini sesuai pendapat Zojic (1971) dalam Hutahaean (1999) bahwa perairan yang berkualitas baik biasanya mempunyai nilai keanekaragman yang tinggi. Lebih jelasnya menurut Willem dan Doris, (1968) dalam Sinaga dan Riwayati,1999 bahwa indeks keanekaragaman dapat digunakan untuk menduga kualitas perairan. Berdasarkan hasil penelitian maka perairan Bedagai tergolong perairan dengan derajat pencemaran sedang.

3. Indeks Keseragaman Makrozoobentos Indeks keseragaman makrozoobentos di Perairan Bedagai berkisar antara 0,707 - 0,894. Indeks keseragaman tertinggi berada pada stasiun II dan terendah pada stasiun III. Indeks keseragaman makrozoobentos berhubungan erat dan saling mempengaruhi dengan indeks dominansi. Dimana bila indeks keseragaman jenis tinggi maka indeks dominansi semakin rendah, demikian sebaliknya.

Apabila suatu komunitas seluruh jenisnya menyebar secara merata (tidak ada spesies yang dominan) maka indeks keseragaman biotanya memiliki nilai yang maksimum. Indeks keseragaman berkisar antara $0-1$, semakin kecil indeks keseragaman suatu komunitas semakin tidak merata penyebaran jumlah individunya pada tiap jenis. Hal ini menunjukkan kecendrungan komunitas biota tersebut didominasi oleh jenis tertentu.

Berdasarkan pada tabel 2, maka stasiun I, II, III dan IV termasuk dalam keseragaman tinggi.

4. Indeks Dominansi

Nilai indeks dominansi berkisar antara 0,11 - 0,9513. Indeks dominansi tertinggi di jumpai pada stasiun IV yaitu 0,9513 . Sedangkan terendah di stasiun I yaitu 0,11 . Tingginya indeks dominansi di stasun IV diakibatkan oleh pembagian jumlah individu tidak merata karena adnya jenis-jenis tertentu yang mendominasi. Keadaan ini bisa terjadi karena faktor kimia fisika sehingga hanya jenis tertentu saja yang dapat bertahan hidup.

Dari hasil penelitian yang telah dilakukan maka dapat diambil kesimpulan bahwa kelimpahan makrozoobentos di Perairan Bedagai berkisar antara 1586,56 - 2692,31 ind $/ \mathrm{m}^{2}$, keanekaragaman dan keseragaman makrozoobentos di Perairan Bedagai tergolong tinggi, dominansi makrozoobentos di Perairan Bedagai stasiun I, II, III tergolong rendah dan stasiun IV tergolong tinggi dan berdasarkan analisis sifat fisika kimia dan karakteristik 
organisme makrozoobentos maka perairan bedagai dapat digolongkan tercemar sedang.

\section{Daftar Pustaka}

Alabastar J.S \& Liod. 1982. Water Qualiy Criteria for Freshwater Fish

Fachrul, M.F. 2007. Metode Sampling Bioekologi. Bumi Aksara. Jakarta.

Hawkes, H.A. 1978. Invertebrate as Indicator of River Water Quality. Jhon Wiley and Sons . Toronto.

Hutahaean, D. I. 1999. Studi Keanekaragaman dan Kelimpahan Makrozoobentos di sungai Sibiru-biru Kec. Biru-biru Kab. Deli Serdang. Skripsi FMIPA.

Odum, E. P. 1971. Dasar-dasar Ekologi. Gadjah Mada University Press. Yogyakarta.

Odum, E. P. 1983. Basic Ecology. Sounders College Publishing. New York.

Pescod, M. B. 1973. Investigation of Rational Effluent and Stream Standard for the Tropical Countries. AIT. Bangkok.

Sastrawijaya,A,T. 1991. Pencemaran Lingkungan. Rineka Cipta. Jakarta.

Sinaga, A dan Riwayati. 1999. Ekologi Perairan. FMIPA IKIP Medan.

Krebs, C. G. 1978. Ecology the Experimental Analysis of Distribution and Abudance. Harper and Raw Pub. New York.

Lee, C. D. S. B. Wang and C.L. Kuo. 1978. Benthic Makroinvertebrate and Fish as Biological Indicator of Water Quality. With References on Water Pollution control in Developping Countries. Bangkok. Thailand. 